\title{
Analysis of Maturity Level Project Management of Software Development In Scrum Framework: Case Research On Tribe Enterprise PT. XYZ
}

\author{
Fakhrul Ridha ${ }^{1}$, Ega Hegarini ${ }^{2}$ \\ Departement of Technology and Engineering, Gunadarma University ${ }^{1,2}$ \\ fakhrulridha@gmail.com¹, hegarini@gmail.com²
}

\begin{tabular}{l}
\hline Article Info \\
\hline Article history: \\
Received 17 February 2020 \\
Revised 27 April 2020 \\
Accepted 24 July 2020 \\
\hline Keyword: \\
Project Management \\
Agile Methodology \\
Scrum \\
Scrum Maturity Model
\end{tabular}

Corresponding Author:

Fakhrul Ridha,

Departement of Technology and Engineering,

Gunadarma University,

Email: fakhrulridha@gmail.com

\begin{abstract}
One of the most widely used product developments now is Agile Development Method. In Agile Development there are several frameworks, one of them is Scrum. This research examines the maturity level of software development project management that applies Scrum framework. The research was conducted using quantitative research methodologies using Scrum Maturity Model. Data was collected by distributing questionnaires to employees at a company that works as a Scrum Master. In addition to the data obtained from the questionnaire, interviews were also conducted to confirm answers from respondents. The interview aims to ensure the answers given by respondents are consistent with documentary evidence carried out through the research of project documents. Then the data analysis is done by assessing the level of maturity of each process in the Scrum framework using Agile Maturity Model (AMM) approach. The results from the analysis of Maturity Level Project Management of Software Development are used to provide recommendations for improvement to achieve a higher level of maturity.
\end{abstract}

(C) This work is licensed under a Creative Commons Attribution-ShareAlike 4.0 International License.

\section{INTRODUCTION}

The development of information technology in an enterprise is a common thing to happen where the use of Information Technology is one tool to help in the process of achieving the business objectives of the organization. The importance of the existence of information technology requires good governance so that the use of information technology can be in accordance with existing business strategies. In the current era of information technology development, the role of software is increasingly important so it is said to be a business enabler for organizations (Applegate, Austin, \& Soule, 2009). Business management itself is faced with conditions that are completely uncertain and sudden and drastic changes. In this condition, agile execution is needed to anticipate continuous changes and higher customer demand. 
Agile process development is the stages of making a detailed process model, system design and manufacturing system in one phase, and using high-level development tools based on an executable process model. In line with Schatten and Schiefer opinion, Traditional Business Process Management cannot move quickly when changes occur, so it is recommended to use the more agile approach to manage business processes to accommodate changes more quickly in the business environment (Schatten \& Schiefer, 2007), (Campanelli \& Parreiras, 2015).

The Agile Maturity Model Framework developed by Patel \& Ramachandran (2009) was then continued by Yin, Figueiredo, \& Miguel (2011) in his research that introduced the Scrum Maturity Model concept. The main objective of the Scrum Maturity Model is to provide guidance for organizations that develop IT projects and support self-improvement by taking a special approach to the role of consumers in the project. Scrum maturity level assessment displays a form that will answer whether the organization has implemented established practices and can present evidence of both physical and implied evidence.

Scrum is an iterative software engineering process to develop and deliver software. The Scrum Framework is a lightweight process. It focuses on increasing the productivity of teams while reducing wastes and redundant activities. Scrum defines some general guidelines with a few rules, roles, artifacts, and events. Nevertheless, all of these components are critical, serve for specific purposes, and they are essential for the successful use of the Scrum framework. ${ }^{1}$

In 2017, PT XYZ first applied the Scrum method in developing new products. But until now, the implementation of Scrum has not been going so well. This can be seen from the percentage of successful sprints from existing project samples, which is only $78 \%$. Sprint is the heart of Scrum, which is a time limit of one month or less in duration, where there is an increment process that is "Completed", can be used and has the potential to be released.

According to Ken Schwaber and Jeff Sutherland (Creators of Scrum Method), the success of using Scrum depends on people who are increasingly animating the five Scrum values, namely commitment, courage, focus, openness, and respect. The successful use of Scrum depends on people who are increasingly animating the five values. ${ }^{2}$ People are personally committed to achieving the goals of Scrum Team. Scrum Team members have the courage to do the best and work on difficult problems. All parties focus on the work within the Sprint and the goals of Scrum Team. Scrum Team and other interested parties agree to be open to all work and challenges in doing the work. Scrum Team members respect each other that they are people who have the ability and independence.

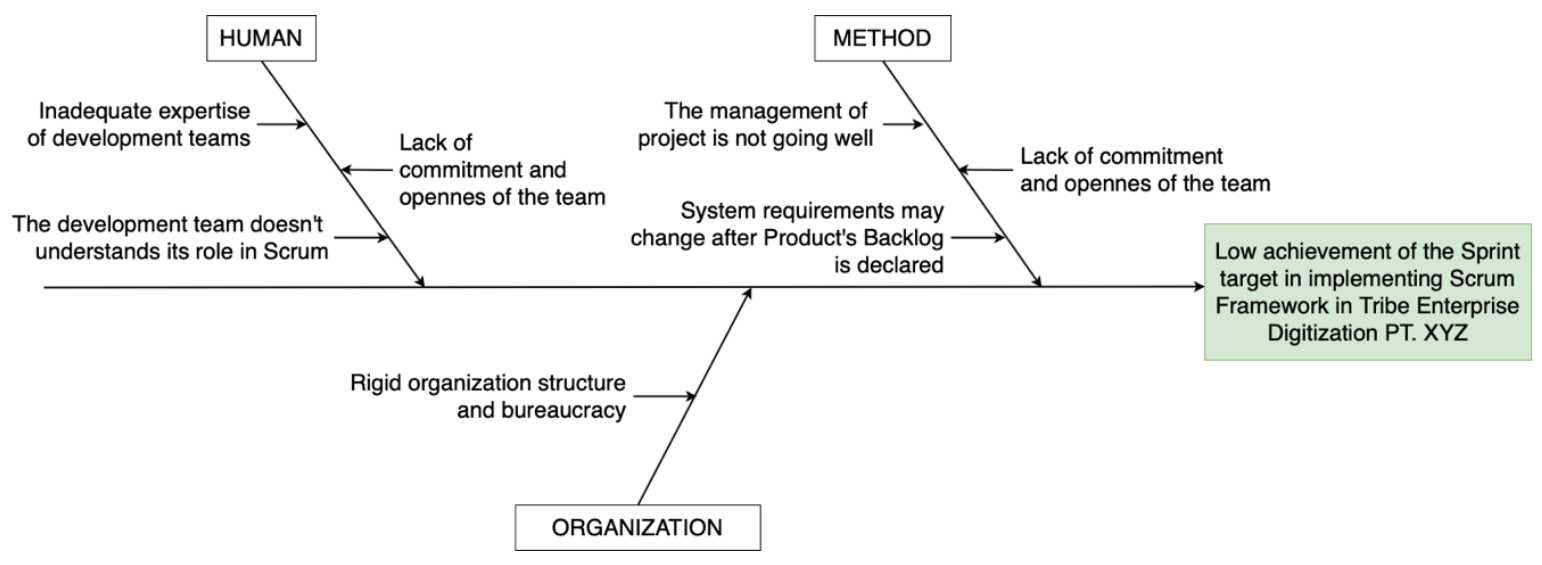

Figure 1. Fish Bone Diagram Problem Root Analysis

\footnotetext{
${ }^{1}$ Scrum Institute. (2010). The Scrum Framework [Online]. Available: https://www.scruminstitute.org/what-is-scrum-the-framework.php

${ }^{2}$ ScrumAlliance. (2009. Scrum Values [Online]. Available: https://www.scrumalliance.org/aboutscrum/values
} 
Figure 1 is a Fish Bone Diagram that divides the root of the problem into four, namely humans, methods, and organization. From the roots of the problems identified, this research is focused on finding out the Maturity Level Project Management of Software Development using the Scrum framework. After that, the authors define research questions as follows: What is the maturity level of the software development project management that applies the Scrum framework in Tribe Enterprise PT XYZ?

Therefore, to answer these problems, in this research the authors conducted an evaluation performance of software development that was applied and provided input to improve future performance.

\section{RESEARCH METHOD}

This research is quantitative research. There are two types of data used in this research, namely primary data and secondary data. Primary data obtained from observations, distributing questionnaires and interviews with research objects. Whereas the secondary data was obtained from a documentation study of software development projects in Tribe Enterprise PT. XYZ Based on the type of data required, the research subjects determined are individuals who act as Scrum Masters in Tribe Enterprise PT. XYZ. There are five squads in Tribe Enterprise PT. XYZ that will be studied are Squad Explore, Squad Buying, Squad Delivery, Squad Assurance, and Squad Partner. A squad is the smallest unit of development in the tribe model. Squads consist of a group of engineers, researchers, designers who work closely together on a specific area of the product.

\section{a) Questionnaire}

There are several ways used to obtain data for this study which are explained as follows:

The questionnaire is a data collection technique that is done by asking written questions to respondents. This method is carried out to obtain input that will be processed into the calculation of the project development maturity level. The questionnaire questions were adapted from questions in the Scrum Maturity Model.

\section{b) Document Study}

Document study is a data collection technique by studying existing documents on written objects such as books, minutes, diaries, rules, etc. The document studied in this study is the documentation of a software development project in Tribe Enterprise Digitization PT. XYZ.

\section{c) Interview}

In addition to data obtained from the questionnaire, interviews were also conducted to confirm answers from respondents. The interview aims to ensure the answers given by respondents are consistent with documentary evidence carried out through the study of project documents. 
The flow of research conducted is presented in Figure 2 below:

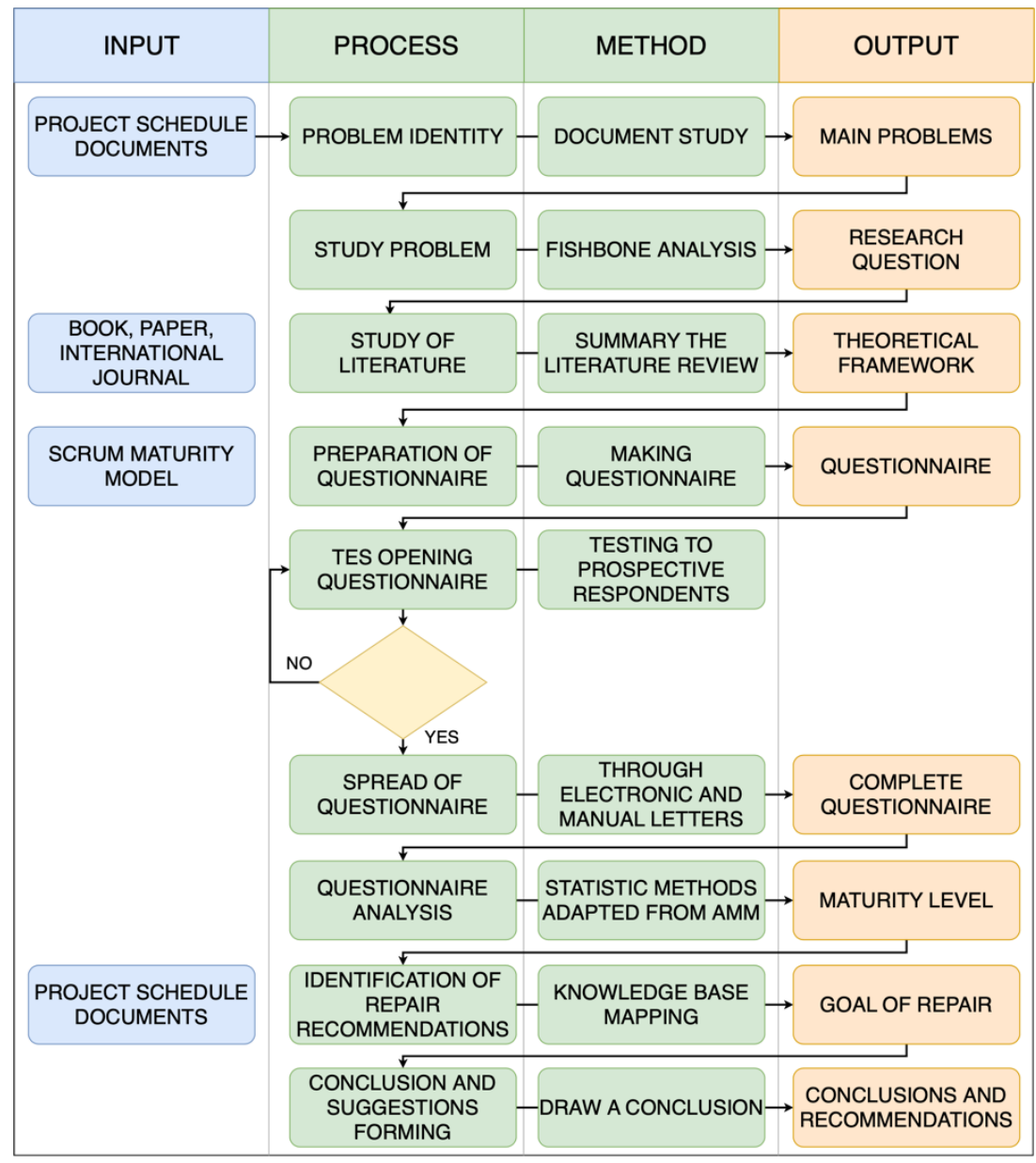

Figure 2. Research Framework

Figure 2 illustrates the research flow. This is a description of the stages of research conducted:

a) Problem Identification

Identification of the problem is done to define the background of the problem that underlies this research. The problem identification process is carried out through the document study method using input from the Tribe Enterprise PT XYZ project development schedule document. Recapitulation of project development data is presented in tabular form which indicates differences in the expected time of project implementation with the reality on the ground. The results of this identification problem are the main problems of research.

b) Deepening Problems

After getting the main problems underlying the research, then the next stage is the process of deepening the problem. The main problem data in the previous stage and understanding of the real conditions are used as input for mapping the problem root using the Fish Bone Diagram analysis method. The results of the deepening problem stage are research questions.

\section{c) Study of Literature}

A literature study is conducted to find theories, research, and methodologies that are relevant to the research questions that have been defined in the previous stages. Input from this process are textbooks, papers and journals. The method is done by way of summarizing, comparing, and look for the difference between literature, criticize, synthesize and summarize the literature. All of this literature is summarized into output in the form of a theoretical framework that underlies the entire study. 


\section{d) Drafting the Questionnaire}

After obtaining a summary of the literature study then conducted a research instrument in this case in the form of a questionnaire. The questions in the questionnaire were adapted from questions in the Scrum Maturity Model. The results of this process will be in the form of a draft questionnaire.

e) Test The Readability of The Questionnaire

Before compiled into the final form, the list of questions must be tested first. To conduct a trial, prospective respondents were chosen as having the same characteristics as the actual research respondents. If after reading the readability test there are still question points that still need to be revised, then the rearrangement of the questionnaire questions will be improved. After that, the test is repeated until the questionnaire is deemed fit to be distributed until it becomes the final questionnaire. If the final questionnaire is deemed fit for distribution, then proceed to the next stage, which is the distribution of questionnaires.

f) Questionnaire Distribution

After the questionnaire has been arranged, the next step is data collection. Data collection is done by distributing questionnaires that have been arranged and final to respondents. The output of this process is a completed questionnaire.

g) Questionnaire Analysis

After the project data according to the list of questions collected the next step is to analyze the questionnaire. The outcome analysis of this questionnaire is the level of maturity of the software development project implementing the Scrum framework.

h) Identify Improvement Targets

After getting the results of the project development maturity level using the Scrum framework, the next step is to identify the improvement targets to achieve a higher level of maturity. This stage is carried out using a method of analyzing KPA (Key Process Area ) based on the Scrum Maturity Model. The results of identifying these improvement targets are recommendations for improvement targets.

i) Making Conclusions and Suggestions

The final step is making conclusions and suggestions based on the results and analysis of the previous stages. Conclusions are generated by taking the main results of the study that are associated with research questions. Suggestions result from learning obtained from the entire research process. The results of this process are the conclusions and research suggestions.

Drafting the questionnaire was carried out with reference to the Scrum Maturity Model (Yin, Figueiredo \& Miguel, 2011). Scrum Maturity Model provides 70 questions for all levels of maturity with 36 questions to measure level two maturity with two general objectives, 27 questions to measure level three maturity with general goals, one question to measure level four maturity with one general target and six questions for measure level five maturity with two general targets.

Scrum Maturity Model Method (Yin, Figueiredo, \& Miguel, 2011) does not explain how to analyze questionnaire data in detail. Therefore, for the purpose of data analysis, a questionnaire was assessed using the Agile Maturity Model (AMM) approach (Patel \& Ramachandran, 2009). The responses to the questionnaire are: "Yes", "Partially", "No", "Not Applicable (N/A)". To identify targets for improvement, identification was carried out through answers to questionnaires that have a value of "Partially," "No," or "Not Applicable (N/A)". Using this criterion, the percentage for each KPA can be calculated as follows:

Where:

$$
\frac{\sum(Y n)+1 / 2 \sum(P n)}{\sum(T n)-\sum(N A n)} \times 100 \%
$$

$\mathrm{Y}_{\mathrm{n}}=$ Number of Yes answers

$P_{n}=$ Number of Partially answers

$\mathrm{T}_{\mathrm{n}}=$ Total Number of the questions

$\mathrm{NA}_{\mathrm{n}}=$ Number of N/A answers. 
The KPA rating is representing the capability level of the assessed KPA. The interpretation of this as following:

- Fully Achieved: $86 \%$ to $100 \%$ there is evidence of a complete and systematic approach to and full achievement of the defined key practices in the assessed KPA. No significant weaknesses exist across the defined organization unit.

- Largely Achieved: $51 \%$ to $85 \%$ there is evidence of sound systematic approach to and significant achievement of the defined key practices in the assessed KPA. Performance of the key practices may vary in some areas.

- Partially Achieved: $16 \%$ to $50 \%$ there is evidence of sound systematic approach to and achievement of the defined key practices in the assessed KPA. Some aspect of achievement may be unpredictable.

- Not Achieved: $51 \%$ to $85 \%$ there is little or no evidence of achievement of the defined key practices in the assessed KPA.

To assess the maturity level in the software development process, all KPA values assessed must be fully achieved (KPA Rating $\geq 86 \%$ for each KPA).

\section{RESULTS AND ANALYSIS}

In measuring the maturity level, the initial stage is evaluating the answers to each item in the questionnaire. For each answer, a supporting document is checked. If the answers given can be proven with supporting documents that are included then the assessment given is in accordance with the contents of the questionnaire answers. However, if the answers given cannot find supporting documents or the supporting documents are incomplete, additional informal interviews are conducted to determine a more appropriate value.

After evaluating all the questions, the next step is to recapitulate the answers to all questions from each project. From this recapitulation, data analysis will then be carried out by assessing the maturity level for each general target. The final results of the assessment of the maturity level in each general target will be interpreted to determine the maturity level as a whole.

Maturity level measurement is done by way of giving value to each of the general objectives to be achieved in the Scrum Maturity Model. Each general target consists of several specific targets. Measuring the maturity level begins with an assessment for each specific target. The recapitulation of the assessment of each specific target will be averaged into the level of maturity of the general target.

- The general objectives of Basic Scrum Management have four specific objectives, namely: 1) There are Scrum roles; 2) There are Scrum artifacts ; 3) There are Scrum meetings; and 4) Sprints are implemented correctly. Common goals Basic Scrum Management on research conducted at the Tribe Enterprise 's gain KPA recapitulation Rating with an average value of $88.61 \%$, so it can be said the general objectives Basic Scrum Management is Fully Achieved. The results of the KPA Rating for Basic Scrum Management general targets can be seen in Table 1 .

Table 1. KPA Results for Basic Scrum Management's General Goal Rating

\begin{tabular}{l|c|c|c|c|c|c}
\hline \multirow{2}{*}{ Special Target } & \multicolumn{5}{c|}{ Squad } & \multirow{2}{*}{ Average } \\
\cline { 2 - 6 } & Explore & Buying & Delivery & Assurance & Partner & \\
\hline There are Scrum roles & $100.00 \%$ & $100.00 \%$ & $100.00 \%$ & $100.00 \%$ & $100.00 \%$ & $100.00 \%$ \\
\hline $\begin{array}{l}\text { There } \\
\text { are Scrum artifacts }\end{array}$ & $77.78 \%$ & $66.67 \%$ & $77.78 \%$ & $72.22 \%$ & $77.78 \%$ & $74.44 \%$ \\
\hline $\begin{array}{l}\text { There } \\
\text { are Scrum meetings }\end{array}$ & $80.00 \%$ & $80.00 \%$ & $80.00 \%$ & $80.00 \%$ & $80.00 \%$ & $80.00 \%$ \\
\hline
\end{tabular}

Ridha, Analysis of Maturity Level Project Management of Software Development In Scrum Framework: Case Research On Tribe Enterprise PT. XYZ 


\begin{tabular}{l|c|c|c|c|c|c}
\hline $\begin{array}{l}\text { Sprints are implemented } \\
\text { correctly }\end{array}$ & $100.00 \%$ & $100.00 \%$ & $100.00 \%$ & $100.00 \%$ & $100.00 \%$ & $100.00 \%$ \\
\hline Average & $\mathbf{8 9 . 4 4 \%}$ & $\mathbf{8 6 . 6 7 \%}$ & $\mathbf{8 9 . 4 4 \%}$ & $\mathbf{8 8 . 0 6 \%}$ & $\mathbf{8 9 . 4 4 \%}$ & $\mathbf{8 8 . 6 1 \%}$ \\
\hline Interpretation & \multicolumn{5}{|c}{ Fully Achieved } \\
\hline
\end{tabular}

- The general objectives of Software Requirement Engineering have three specific objectives: 1) The definition of a Product Owner is clear; 2) Product Backlog Management; 3) a successful Sprint Planning Meeting. Of the three specific targets that have been assessed, then a recapitulation is carried out to determine the final KPA Rating for the general target. Recapitulation result shows that the average of KPA Rating for Software Requirement Engineering general target is $78.06 \%$ with the interpretation of Largely Achieved. The results of the KPA Rating for Basic Scrum Management general targets can be seen in Table 2.

Table 2. KPA Rating Results, with the General Target Software Requirement Engineering

\begin{tabular}{|c|c|c|c|c|c|c|}
\hline \multirow{2}{*}{ Special Target } & \multicolumn{5}{|c|}{ Squad } & \multirow{2}{*}{ Average } \\
\hline & Explore & Buying & Delivery & Assurance & Partner & \\
\hline $\begin{array}{l}\text { The Product Owner definition } \\
\text { is clear }\end{array}$ & $87.50 \%$ & $87.50 \%$ & $87.50 \%$ & $87.50 \%$ & $87.50 \%$ & $87.50 \%$ \\
\hline Product Backlog Management & $58.33 \%$ & $50.00 \%$ & $58.33 \%$ & $58.33 \%$ & $58.33 \%$ & $56.67 \%$ \\
\hline $\begin{array}{l}\text { Successful Sprint Planning } \\
\text { Meeting }\end{array}$ & $100.00 \%$ & $91.67 \%$ & $100.00 \%$ & $100.00 \%$ & $58.33 \%$ & $90.00 \%$ \\
\hline Average & $81.94 \%$ & $76.39 \%$ & $81.94 \%$ & $81.94 \%$ & $68.06 \%$ & $78.06 \%$ \\
\hline Interpretation & \multicolumn{6}{|c|}{ Largerly Achieved } \\
\hline
\end{tabular}

- Common goals Customer Relationship Management has three specific objectives, namely: 1) There is a Completion definition; 2) Product Owner Available; and 3) Successful Sprint Review Meeting. From the three specific objectives contained in the common goal of Customer Relationship Management, acquired the recapitulation of KPA Rating with an average value of $81.67 \%$ so we can say this common goal Largely Achieved. Assessment results for KPA Rating for common goals Customer Relationship Management can be viewed in Table 3.

Table 3. KPA Rating Results, with the General Target Customer Relationship Management

\begin{tabular}{l|c|c|c|c|c|c}
\hline \multirow{2}{*}{\multicolumn{1}{c}{ Special Target }} & \multicolumn{5}{c|}{ Squad } & \multirow{2}{*}{ Average } \\
\cline { 2 - 6 } & Explore & Buying & Delivery & Assurance & Partner & \\
\hline There is a "Done" Definition & $50.00 \%$ & $50.00 \%$ & $50.00 \%$ & $50.00 \%$ & $50.00 \%$ & $50.00 \%$ \\
\hline Product Owner Available & $100.00 \%$ & $100.00 \%$ & $100.00 \%$ & $100.00 \%$ & $100.00 \%$ & $100.00 \%$ \\
\hline $\begin{array}{l}\text { Successful Sprint Review } \\
\text { Meeting }\end{array}$ & $100.00 \%$ & $75.00 \%$ & $100.00 \%$ & $100.00 \%$ & $100.00 \%$ & $95.00 \%$ \\
\hline
\end{tabular}




\begin{tabular}{l|c|c|c|c|c|c}
\hline Average & $83.33 \%$ & $75.00 \%$ & $83.33 \%$ & $83.33 \%$ & $83.33 \%$ & $\mathbf{8 1 . 6 7 \%}$ \\
\hline Interpretation & \multicolumn{5}{|c}{ Largerly Achieved } \\
\hline
\end{tabular}

- The general goals of Iteration Management have four specific objectives, namely: 1) Management of Sprint Backlog; 2) planned iteration; 3) Measured velocity; 4) successful Daily Scrum. From the four specific targets, the KPA Rating recapitulation results with an average value of $68.07 \%$ so that it can be said that the general goal of this Iteration Management is Largely Achieved. The results of the KPA Rating for the general goals of Iteration Management can be seen in Table 4.

Table 4. KPA Rating Results, with the General Target Iteration Management

\begin{tabular}{l|c|c|c|c|c|c}
\hline \multirow{2}{*}{ Special Target } & \multicolumn{5}{c|}{ Squad } & \multirow{2}{*}{ Average } \\
\cline { 2 - 6 } & Explore & Buying & Delivery & Assurance & Partner & \\
\hline $\begin{array}{l}\text { Management of the Sprint } \\
\text { Backlog }\end{array}$ & $71.43 \%$ & $71.43 \%$ & $71.43 \%$ & $71.43 \%$ & $71.43 \%$ & $71.43 \%$ \\
\hline Iteration is planned & $37.50 \%$ & $37.50 \%$ & $75.00 \%$ & $50.00 \%$ & $37.50 \%$ & $47.50 \%$ \\
\hline Measured velocity & $60.00 \%$ & $60.00 \%$ & $60.00 \%$ & $60.00 \%$ & $60.00 \%$ & $60.00 \%$ \\
\hline Successful Daily Scrum & $91.67 \%$ & $91.67 \%$ & $91.67 \%$ & $100.00 \%$ & $91.67 \%$ & $93.33 \%$ \\
\hline Average & $\mathbf{6 5 . 1 5 \%}$ & $\mathbf{6 5 . 1 5 \%}$ & $\mathbf{7 4 . 5 2 \%}$ & $\mathbf{7 0 . 3 6 \%}$ & $\mathbf{5 6 . 3 1 \%}$ & $\mathbf{6 8 . 0 7 \%}$ \\
\hline Interpretation & & \multicolumn{5}{c}{ Largerly Achieved } \\
\hline
\end{tabular}

- The general goal of Standardized Project Management has only a specific goal which is "standardized project management". The recapitulation results show that the average value obtained by the five squads is $50.00 \%$ so that it can be said that this general target is Partially Achieved. KPA Rating assessment results for the general objectives of Standardized Project Management can be seen in Table 5.

Table 5. KPA Rating Results, with the General Target Iteration Management

\begin{tabular}{l|c|c|c|c|c|c}
\hline \multirow{2}{*}{ Special Target } & \multicolumn{5}{c|}{ Squad } & \multirow{2}{*}{ Average } \\
\cline { 2 - 6 } & Explore & Buying & Delivery & Assurance & Partner & \\
\hline Standardized project management & $50.00 \%$ & $50.00 \%$ & $50.00 \%$ & $50.00 \%$ & $50.00 \%$ & $50.00 \%$ \\
\hline Average & $\mathbf{5 0 . 0 0 \%}$ & $\mathbf{5 0 . 0 0 \%}$ & $\mathbf{5 0 . 0 0 \%}$ & $\mathbf{5 0 . 0 0 \%}$ & $\mathbf{5 0 . 0 0 \%}$ & $\mathbf{5 0 . 0 0 \%}$ \\
\hline Interpretation & \multicolumn{6}{c}{ Partially Achieved } \\
\hline
\end{tabular}

- The general objectives of Standardized Performance Management have four specific objectives: 1) A successful Sprint Retrospective and 2) Positive indicators. From the five squads studied, the KPA Rating recapitulation was obtained with an average value of $78.33 \%$ so that it can be said that this general target is Largely Achieved. KPA Rating of assessment results for the general objectives Performance Management can be found in Table 6 . 
Table 6. KPA Rating Results, with the General Target Standardized Performance Management

\begin{tabular}{l|c|c|c|c|c|c}
\hline \multirow{2}{*}{ Special Target } & \multicolumn{5}{c|}{ Squad } & \multirow{2}{*}{ Average } \\
\cline { 2 - 6 } & Explore & Buying & Delivery & Assurance & Partner & \\
\hline Successful Sprint Retrospective & $83.33 \%$ & $66.67 \%$ & $83.33 \%$ & $66.67 \%$ & $83.33 \%$ & $76.67 \%$ \\
\hline Positive indicator & $83.33 \%$ & $83.33 \%$ & $66.67 \%$ & $83.33 \%$ & $83.33 \%$ & $80.00 \%$ \\
\hline Average & $\mathbf{8 3 . 3 3 \%}$ & $\mathbf{7 5 . 0 0 \%}$ & $\mathbf{7 5 . 0 0 \%}$ & $\mathbf{7 5 . 0 0 \%}$ & $\mathbf{8 3 . 3 3 \%}$ & $\mathbf{7 8 . 3 3 \%}$ \\
\hline Interpretation & \multicolumn{6}{|c|}{ Largerly Achieved } \\
\hline
\end{tabular}

From the results of maturity level assessment for each of the general targets, a recapitulation of KPA Rating obtained to determine the overall maturity level of Tribe Enterprise. Acquisition of KPA Ratings on each general target will be interpreted to determine whether a general target is in the position of Fully Achieved, Largely Achieved, Partially Achieved, or Not Achieved.

Table 7. KPA Rating Interpretation Results

\begin{tabular}{|c|c|c|c|c|c|c|c|c|}
\hline \multirow{2}{*}{ Level } & \multirow{2}{*}{$\begin{array}{c}\text { General } \\
\text { Target }\end{array}$} & \multirow{2}{*}{$\begin{array}{c}\text { KPA Rating } \\
\text { /Interpretation }\end{array}$} & \multicolumn{5}{|c|}{ Squad } & \multirow{2}{*}{ Average } \\
\hline & & & Explore & Buy & Delivery & Assurance & Partner & \\
\hline \multirow{4}{*}{2} & \multirow{2}{*}{$\begin{array}{l}\text { Basic Scrum } \\
\text { Management }\end{array}$} & KPA Rating & $89.44 \%$ & $86.67 \%$ & $89.44 \%$ & $88.06 \%$ & $89.44 \%$ & $88.61 \%$ \\
\hline & & Interpretation & $\mathrm{F}$ & $\mathrm{F}$ & $\mathrm{F}$ & $\mathrm{F}$ & $\mathrm{F}$ & $\mathbf{F}$ \\
\hline & \multirow{2}{*}{\begin{tabular}{|l} 
Software \\
Requirements \\
Engineering
\end{tabular}} & KPA Rating & $81.94 \%$ & $76.39 \%$ & $81.94 \%$ & $81.94 \%$ & $68.06 \%$ & $78.06 \%$ \\
\hline & & Interpretation & $\mathrm{L}$ & $\mathrm{L}$ & $\mathrm{L}$ & $\mathrm{L}$ & $\mathrm{L}$ & $\mathbf{L}$ \\
\hline \multirow{4}{*}{3} & \multirow{2}{*}{$\begin{array}{l}\text { Customer } \\
\text { Relationship } \\
\text { Management }\end{array}$} & KPA Rating & $83.33 \%$ & $75.00 \%$ & $83.33 \%$ & $83.33 \%$ & $83.33 \%$ & $81.67 \%$ \\
\hline & & Interpretation & $\mathrm{L}$ & $\mathrm{L}$ & $\mathrm{L}$ & $\mathrm{L}$ & $\mathrm{L}$ & $\mathbf{L}$ \\
\hline & \multirow{2}{*}{$\begin{array}{l}\text { Iteration } \\
\text { Management }\end{array}$} & KPA Rating & $65.15 \%$ & $65.15 \%$ & $74.52 \%$ & $70.36 \%$ & $56.31 \%$ & $66.30 \%$ \\
\hline & & Interpretation & $\mathrm{L}$ & $\mathrm{L}$ & $\mathrm{L}$ & $\mathrm{L}$ & $\mathrm{L}$ & $\mathbf{L}$ \\
\hline \multirow{2}{*}{4} & \multirow{2}{*}{$\begin{array}{l}\text { Standardized } \\
\text { Project } \\
\text { Managemen } \\
\end{array}$} & KPA Rating & $50.00 \%$ & $50.00 \%$ & $50.00 \%$ & $50.00 \%$ & $50.00 \%$ & $50.00 \%$ \\
\hline & & Interpretasi & $\mathrm{P}$ & $\mathrm{P}$ & $\mathrm{P}$ & $\mathrm{P}$ & $\mathrm{P}$ & $\mathbf{P}$ \\
\hline \multirow{2}{*}{5} & \multirow{2}{*}{$\begin{array}{l}\text { Performance } \\
\text { Management }\end{array}$} & KPA Rating & $83.33 \%$ & $75.00 \%$ & $75.00 \%$ & $75.00 \%$ & $83.33 \%$ & $78.33 \%$ \\
\hline & & Interpretasi & $\mathrm{L}$ & $\mathrm{L}$ & $\mathrm{L}$ & $\mathrm{L}$ & $\mathrm{L}$ & $\mathbf{L}$ \\
\hline
\end{tabular}

Suggested improvement recommendations are set for each maturity level. For maturity level 2, it is recommended to be able to achieve the general goal of Software Requirement Engineering that has not been achieved because it is still in the position of Largely Achieved, where Product Owners need to be equipped with knowledge related to methods or techniques in determining priorities and equipped with business-related knowledge in order to be able to determine priority points on the Product Backlog by considering based on business value. Furthermore, the Product Owner also needs to have an understanding of a clear and long-term product vision. Recommendations for improvement for maturity level 3 are suggested to improve practices on specific targets related to customer relationship management and iteration management. The practices referred to consist of two practices for the specific target "There is a Completion definition", two practices for the specific goal of " Sprint Backlog Management ", three practices for the specific target "Planned Iteration", and two practices for the specific target " Measured Velocity ". Further improvement recommendations for maturity level 4 are suggested to improve practice on specific 
targets related to project management standardization. Then recommendations for improvement for maturity level 5 are suggested for improving practices on specific objectives related to project performance management. The practices referred to consist of three practices for the specific objectives of a " successful Sprint Retrospective Meeting " and three practices for specific objectives of a "positive indicator".

\section{CONCLUSION}

The measurement results of the maturity level obtained that Tribe Enterprise PT. XYZ is still at maturity level 2 in the maturity level of software development project management. To achieve a higher level of maturity, improvements are needed in the software development process. The improvement target is obtained by identifying the practices that must be carried out at each general goal for each level where the KPA Rating has not been fully achieved. Recommendations for improvement targets are obtained from specific targets of each general target where KPA Rating still not fully achieved or the KPA Rating $<86 \%$. KPA Ratings that have not yet been achieved are fully mapped with knowledge-based practices that should be carried out to achieve maturity at each level by Scrum Maturity Model. The choice of practice is based on the results of the questionnaire assessment of the question points that have a value of "No" and "Partial".

\section{REFERENCES}

[1] K. Schwaber and B. Mike, Agile Software Development with Scrum (Series in Agile Software Development), Prentice Hall, 2002.

[2] M. C. Layton and S. J. Ostermiller, Agile Project Management For Dummies, 2nd Edition, Canada: John Wiley \& Sons, Inc., 2017.

[3] K. C. Dewi, P. I. Ciptayan and I. W. R. Wijaya, "Agile Project Management Pada Pengembangan E-Musrenbang Kelurahan Benoa Bali," Jurnal Teknologi Informasi dan Ilmu Komputer (JTIIK), pp. 723-730, 2017.

[4] A. Nuraminah, "Analisis Tingkat Kematangan Manajemen Proyek Pengembangan Perangkat Lunak Menggunakan Scrum Maturity Model: Studi Kasus PT. XYZ," ISTATEMENT STIMIK ESQ, vol. 2, 2016.

[5] R. A. Azdy and A. SN, "Implementasi Scrum Pada Pengembangan Software Terdistribusi," semnasIF 2012, 2012.

[6] C. Patel and M. Ramachandran, "Agile Maturity Model (AMM): A Software Process Improvement framework for Agile Software Development Practices," Int.J. of Software Engineering, vol. 2, 009.

[7] A. Yin, S. Figueiredo and M. M. da Silva, "Scrum Maturity Model - Validation for IT organizations se roadmap to develop software centered on the client role," ICSEA, 2011.

[8] H. Kniberg, Scrum and XP from the Trenches, C4Media, 2007.

[9] Z. Li-na and S. Dan, "Research on Combining Scrum with CMMI in Small and Medium Organizations," International Conference on Computer Science and Electronics Engineering, 2012.

[10] K. S. Rubin, Essential Scrum: A Practical Guide to the Most Popular Agile Process (Addison-Wesley Signature): A Practical Guide To The Most Popular Agile Process, Addison-Wesley Professional, 2012.

[11] L. M. Applegate, R. D. Austin and F. W. McFarlan, Corporate Information Strategy and Management, New York: McGraw-Hill, 2009.

[12] K. Schwaber, Agile Project Management with Scrum, Redmond: WA: Microsoft Press, 2004. 


\section{BIOGRAPHY OF AUTHORS}

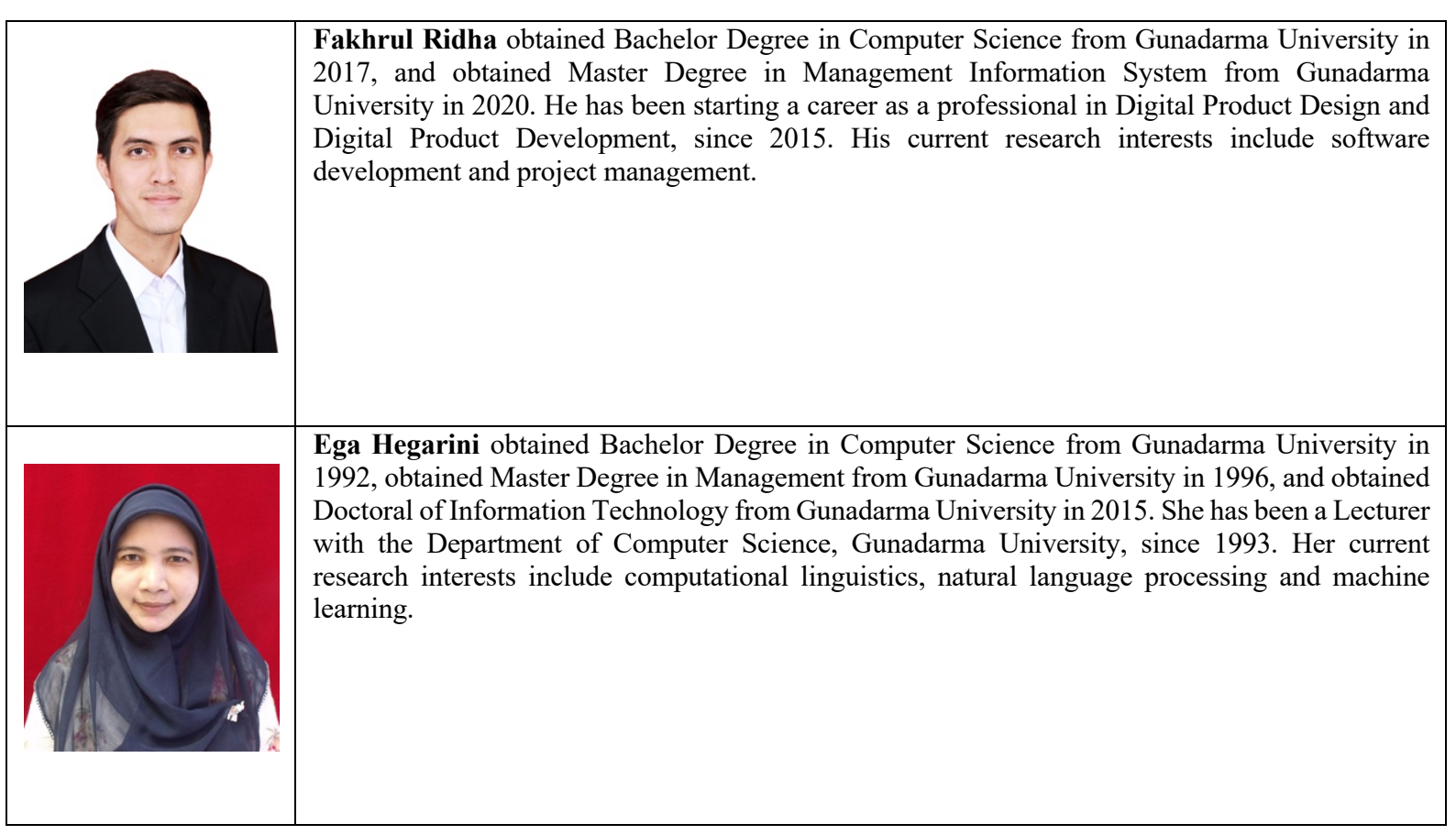

